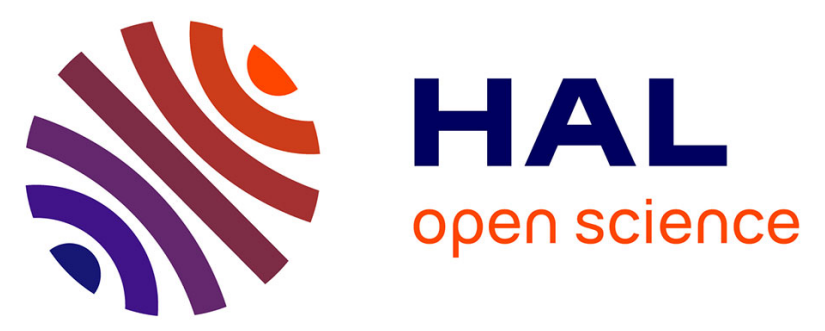

\title{
Innovative product's supply chain: How to model it
}

Brunelle Marche, Vincent Boly, Laure Morel, Frédérique Mayer, J. Roland

Ortt

\section{To cite this version:}

Brunelle Marche, Vincent Boly, Laure Morel, Frédérique Mayer, J. Roland Ortt. Innovative product's supply chain: How to model it. 2017 International Conference on Engineering, Technology and Innovation (ICE/ITMC), Jun 2017, Funchal, Portugal. 10.1109/ICE.2017.8279887 . hal-01838119

\section{HAL Id: hal-01838119 https://hal.science/hal-01838119}

Submitted on 15 Oct 2018

HAL is a multi-disciplinary open access archive for the deposit and dissemination of scientific research documents, whether they are published or not. The documents may come from teaching and research institutions in France or abroad, or from public or private research centers.
L'archive ouverte pluridisciplinaire HAL, est destinée au dépôt et à la diffusion de documents scientifiques de niveau recherche, publiés ou non, émanant des établissements d'enseignement et de recherche français ou étrangers, des laboratoires publics ou privés. 


\section{Innovative Product's Supply Chain: How to Model it}

\author{
Brunelle MARCHE, Vincent BOLY, Laure MOREL, \\ Frédérique MAYER \\ Université de Lorraine \\ ERPI- Equipe de recherche sur les Processus Innovatifs \\ Nancy, France \\ \{brunelle.marche, vincent.boly, laure.morel, \\ frederique.mayer\}@univ-lorraine.fr
}

\author{
J. Roland ORTT \\ Faculty of Technology \\ Policy and Management \\ Delft, the Netherlands \\ J.R.Ortt@tudelft.nl
}

\begin{abstract}
The emergence of innovative products impacts the ecosystem of the company and more precisely its supply chain. Therefore, anticipating the reorganization of the latter is an important challenge for many innovative companies to ensure the success of their product. From a systematic review of the literature and case studies, this article highlights the descriptive elements of a supply chain. A methodology is developed leading to a representation model for any supply chain. This model is confronted with several case studies to verify its pertinence before being confronted in real time with a case study. The model will be implemented and validated according to the results of this study. Subsequently, a methodology will be developed to help innovative companies anticipate the reorganization of the supply chain supporting their innovation..
\end{abstract} Model

Keywords-Supply chain; Innovation; Systemic approach;

\section{INTRODUCTION}

A supply chain (SC) regroups all companies involved in the production and supply of a final product, so every product has its own supply chain. A well-designed and coordinated supply chain that fits a particular product leads to competitive advantages. Therefore, international competition is also existing at SC level [1]. As emergence of a new product impacts the organization of a company, it is clear that every new products impacts also the supply chain: changes in the stakeholders' interrelations, emergence or disappearance of stakeholders [2], evolution of new skills in the supply chain... Indeed, in innovation, matching the characteristics of a new product and its associated supply chain appears as a key success factor [3], [4]. So the configuration of the supply chain plays an important role in the development of the final product. The supply chain has to be adapted to the specification of the new product in terms of processes, skills ...

Therefore, particular attention is drawn toward forecasting of a product innovation's impacts on the whole supply chain. For that, a description and modeling of the supply chain are required to better understand the way a supply chain evolves with the emergence of a new product. This includes the collection of data about the relations between the product requirements and the potential transformation within the supply chain.
This research leads to a better visualization of the importance of the supply chain design at the early stage of product development. Indeed, our purpose is to contribute to the modeling of the ideal supply chain taking into account the emerging data during its design phase.

This article is structured as follows. Initially, existing theories related to our research work will be proposed. Then, the methodology is presented and the results are detailed. The model is described in detail. Finally, the analysis and conclusion of this research are presented.

\section{RELATION TO EXISTING THEORIES AND WORK}

\section{A. The product and the supply chain viewed from a systemic point of view}

According to [5], a system is a "set of dynamically interacting elements organized according to a goal". In this approach, [6] goes further by considering the system as " an organized global unit of interrelations between elements or individuals". In this latter definition, the organization refers to "the arrangement of relations between components or individuals that produces a complex unit or system".

The systemic approach facilitates the study of objects in their complexity. According to this approach, an object is a system or a component of a system. A system is defined as a set of elements in interaction, in permanent relation with its environment [5]. All types of system have architectures [7].

For reasons of interrelationships, system entities require a holistic approach and should not be considered as a simple sum of theirs parts [8]. In this research the object may be the innovative product or the SC.

\section{B. The product}

The product is an object coherent with its environment [9]. It is composed of independent elements performing functions, organized as a whole where each element function contributes to define the global function of the expected product. This vision corroborates the definition of system proposed previously. As with any complex system, the product architecture refers to components and interactions in the physical artifact such as hardware [7]. According to Ulrich, the product architecture refers to the allocation of functions to physical components taking into account the organization of the functional elements, the mapping of these elements into 
physical components and the specification of the interfaces between these components which interact [10]. Then, the product is structured hierarchically [11]. Thus, the decomposition of the product into small elements such as subsystems, modules and components seems coherent to apprehend the product as a whole. The integration of these elements impacts the overall performance of the system [7].

The complex architecture of a product often requires the involvement of many companies in its design and manufacture. Thus data collection to design the product is highly complicated, especially during the early stages of its life cycle [12].

\section{The supply chain}

The supply chain (SC) is a complex notion. Reference [1] characterizes a supply chain as a network of companies involved in processes, upstream and downstream, that creates value in the form of a product or service to a final customer. Reference [13] describe a supply chain as "a set of companies belonging to different competitive spheres, linked together by coordinated and cooperative vertical relationships, contributing to the realization of the same good, sharing the same representation of the issues affecting demand, employment, financing and supply". These definitions highlight that the supply chain can be considered as a system.

Thus, the company ecosystem is made up with stakeholders, each of which has specific knowledge and materials. Companies are linked by physical, informational or financial flows [14] and each contributes to value creation with technological skills, equipment, organization and materials that are priced in competition. [15], [16].

Like any complex system, the supply chain architecture has to highlight how companies work together to accomplish a task and lead to a common goal. More specifically, the architecture of the supply chain consider [7] :

- The hierarchical decomposition of the supply chain into companies

- The division of work between companies

- The relationships between companies, also named network of interactions.

There is an implicit link between the architecture of the product and the architecture of the supply chain. Requirements from the product influence the structure of the supply chain.

\section{RESEARCH APPROACH}

Many models and behaviors resulting from innovation and design management come from a positivist approach through the control of variables. However, the product design is a complex phenomenon that depends on the interaction of many stakeholders. Research in the field of design aims to understand what leads to improvement in practice to increase the chances of producing a successful product [17], [18]. The impact of design decisions can be unknown for months or even years because of the delay between the implementation of a product design and its ultimate market results. The design deals with human interactions with artifacts and situations that contain many uncertainties [19].

The empiricism is based on the idea that knowledge is constructed from the observation of phenomena, the understanding of which enables to infer laws. Therefore, empiricism is a discovery of the world through experience [20]. It contributes to the constructivist paradigm which considers that reality is constructed and that it is selforganized around a finality [20].

The phenomenological paradigm focuses on the understanding of events and the search for a more desirable future for the actors [21]. Thus, phenomenology belongs to constructivist paradigm. This approach contributes to knowledge while providing direct benefits for companies. This methodological approach is consistent with the ambitions of this research leading to a relevant supply chain model to support innovative companies [22].

In an empirical reasoning, one of the strategies of analysis concerns the use of a theoretical model. A theory is built on the study of examples and allows the detection and identification of invariants, to model and to anticipate future developments of a problem.

Used extensively in empirical research, the case study is adapted to questions about the more or less implicit interactions linked to a phenomenon. The potential of the case study lies in its ability to highlight the observation of the singularity of the problem participating in the understanding of a problem likely to be repeated [23].

\section{A. Research design}

Inspired by the methodology proposed by [22], the research was carried out in four phases: a literature review, an observation campaign, the development of the model and finally its validation. Each step is described in detail (Fig.1).

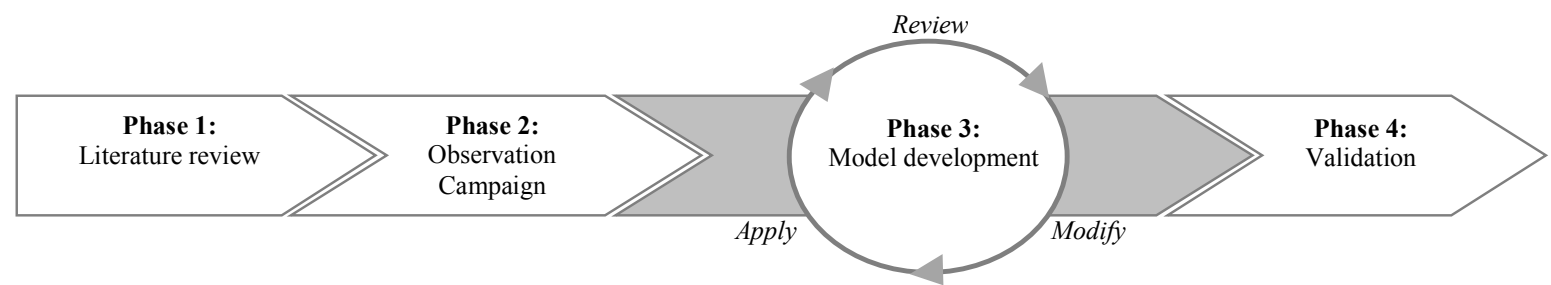

Fig 1. Implemented methodology inspired by [22] 
1) Phase 1: literature review

The literature review helps to identify constitutive elements of a supply chain by synthesizing all relevant studies on this subject. The structure of the supply chain is described and justified thanks to a state of the art from 1960 to 2016.

\section{2) Phase 2: observation campaign}

The exploratory study focuses on three innovative companies that launched their new product on the market. This leads to a better understanding of the design of a new product supply chain, in parallel with the design of the related product. The heterogeneity of the case studies highlights the recurrence of phenomena during the structuring of the supply chain, from the initial stages of product design to its launch on the market. Data from each case study are collected in three different ways:

- Empirically based on an in-depth study of the literature

- Through meetings and interviews with the CEO

- Immersion and observation within the companies from the initial stages of product design to launching.

Phenomena from the case studies can be used to illustrate and check evidence from the literature review.

\section{3) Phase 3: model development}

These different exploratory cases and the evidence provided by the literature lead to the development of a representation model of the supply chain. Models are used to visualize a part of the real world to simplify its understanding. The supply chain model we create is meant to be used as a prospective tool for companies designing an innovative product. It is applied to a company whose product is still in the design stage, the structuring of its future supply chain being indispensable to guarantee its industrialization.

Modeling involves knowing how to represent information in order to better communicate it. A system is a model of an original made by an observer, but it is not the original itself [24]. Then, the determination of the system depends on the frame of reference of the observer.

To transmit the information, the use of modeling language, standardized formalism, is required. UML are discursive languages where information is communicated as text [25]. The UML language is a standardized visual specification language for modeling objects that includes a graphical notation used to create an abstract model of a system.

It is based on a decomposition of the model into "views", represented in diagrams. Each view is dedicated to the representation of a particular aspect of the system: requirements, structures, behaviors [26]. In addition, MEGA International Software is a software solution for system modeling. It facilitates process definition, control of operations.
4) Phase 4: validation

A fourth company initiating the design of a new product is finally studied to validate the model and evaluate its applicability. Reasons to select this company are:

- The question of the industrialization of the product arises, the design phase coming to end;

- The decomposition of the product is possible layer by layer;

- The ideal supply chain is not determined, thus, the industrialization of the product is not determined;

- The coordination between actors is not yet envisaged;

- The product requires processes and highly technical skills.

Each part of the model is filling out to highlight the consistency of the model and validates by the company.

\section{FINDINGS}

\section{A. Phase 1: literature review}

The systematic review of the literature shows that the concept of a supply chain can be characterized by invariants. It is a complex system involving stakeholders, flows and processes. [28]-[31].

Organized in network [31], [32], the supply chain is composed of a set of complementary companies that are jointly involved in the development of a product [32]. It is composed of stakeholders such as suppliers, logistics suppliers, component and final product manufacturers [33], wholesalers and resellers [34]. The, a supply chain has to comprise at least two entities linked together by flows[14].

A supply chain is characterized by three minimum flows [35] :

- A physical flow corresponding to a set of units in circulation in space [36] such as materials, components or finished products;

- A financial flow corresponding to the monetary counterpart of the physical flow [37];

- A information flow coordinating the financial and physical flows between each company [38].

A supply chain is also a mapping of processes whose value is gradually added to a product delivered to the final customer [39]. These processes are composed of a combination of heterogeneous activities organized as a sequential network [36], [40]. These activities can be decomposed into homogeneous tasks that contribute to the transformation of inputs onto outputs [41]. All these tasks are carried out by one or more individuals with specific skills [42]. A task is generated by an activity linked to the product to be realized and is assigned to a company that is a member of the supply chain [43], [44].

Technologies, equipments, skills linked to the processes and activities create value. The final value of a product results from these activities grouped into processes [42], it 
corresponds to the sum of the values contributed by each of the member companies in the supply chain.

In his research, [45] we assume that value can take various forms: financial, strategic; intellectual, commercial, functional, and sustainable. The value is, linked to many different aspects, such as the captive aspect of the customer, the associated development possibilities, the degree of novelty, notoriety or the pleasure generated.

\section{B. Phase 2: observation campaign}

\section{1) Presentation of studied companies}

In this phase, several cases are studied. Companies launching innovative products were studied as well as the associated supply chain. The strategic fields of activity of these companies are deliberately very different to best determine the invariants present within each supply chain. The emerging products in these cases differ in terms of success, once on the market.

\section{Company A is a company in the watch industry.}

Originally, the watch industry is organized in the form of a cartel where each company carries out specific tasks according to its expertise. The acquisition of skills is not allowed. This strict division in activity impacts the length of the supply chain; which includes many actors. Indeed, there were up to one hundred and fifty companies involved in the design of the watch [46]. To counter the emergence of low-end watches, one company of the cartel decided to offer a customizable plastic watch. The new product radically changes the organization of the supply chain. The first experiments were on plastic and used specialized equipment loaned by equipment manufacturers. At the earliest stages of the new product development, data about future manufacturing are underlined. The choice of ultrasonic welding [47], manufacturing process for the new product, impacts the field of skills, equipment and also manufacturing decisions. In fact, from manual to industrial manufacturing, production changes: production rates and planning are adapted to the machines. Company A adopts knowledge of plastic manufacturing and selects its suppliers to match the new watch. Process automation reduces the number of components, thus reducing the number of companies within the supply chain [47]. The watch becomes a fashion accessory and it catches the attention of new customers and gradually imposes itself on the market.

All these changes lead to a reorganized supply chain: companies have disappeared, others have emerged (those in the field of plastics processing). Company A has developed its expertise and intervenes in several stages of the new product manufacturing (its production, its marketing).

\section{Company B is an SME in the electronics sector.}

Originally, it was a service company offering methodologies to characterize the functioning of an industrial production system. The company's activities consisted of taking measurements and processing results in order to optimize the system in the field of chemistry. In collaboration with a research laboratory, it develops an acquisition system that combines computer, measurement and video. The skills related to the data measurement and processing remain the same while other competences, specific to the valorization of the new product, appear. The data processing process is evolving and takes account of this new acquisition unit. With this new product, company B opens up to other markets, in the medical field and is committed to an $\mathrm{R}$ \& D approach. To support its offer, the company is surrounded by suppliers specialized in sensors before embarking on the development of its own sensors. More recently, the company has improved its range of sensors by focusing on embedded systems. It acquired the equipment and skills in electronics and embedded electronics to develop its expertise. This new orientation has broadened the company's market and allowed it to develop its business, in particular its commercial activities. At present, the company manufactures a set of sensors and data processing software for medicine, neuromarketing, research domain and human-machine interfaces. It offers a data acquisition system and software to synchronize measurements of human activity.

The supply chain of company B's product was gradually established, in keeping with its environment, which enabled the company to support its influence and occupy the most important place.

\section{Company $\mathrm{C}$ is an SME in the equine sector.}

Originally, company $\mathrm{C}$ manufactures and sells highperformance PVC barriers for the racing world. The company manages manufacturing by extrusion, storage, distribution, marketing, sales and installation of barriers. As the company manages most of the activities required to manufacture and upgrade the product, the supply chain is simple, without too many intermediaries.

To complement its product range, the company has developed highly secure fences to reduce the risk of injury to horses and riders. The existing obstacles were made of wood or stone, locally and by hand. There was therefore no supply chain of its product. With its new product, company $\mathrm{C}$ proposes an industrial product and takes advantage of the expertise of specialized companies to improve the safety aspect during horse races. Rotomolding is the main manufacturing process to meet the company's needs. The company mobilized external specialists and invested in cast iron molds used in this process. New skills, new for the company, appear in the industry and lead to the integration of new companies, specialized in polyethylene to design products. The company uses its core related know-how to develop its products and enter new markets.

Company $\mathrm{C}$ has built a new supply chain around its product, coordinating the different stakeholders to meet the requirements of its product. It is the leader of the supply chain. 


\section{2) Summary of cross-observations}

This research phase aims at identifying the recurrent or common elements that could influence the development of representation model of a supply chain. The key points are summarized as follows.

A supply chain has to include at least two companies, of various typologies.

The company A's supply chain is made up of suppliers of plastic materials, suppliers of watch components (mechanisms, movements...), company A transforming the material into a plastic watch, and retailers (sports shops, jeweler...).

The company B's supply chain is made up of suppliers of sensors, suppliers of electronic components, companies specializing in video processing, company $\mathrm{B}$ and distributors.

The company C's supply chain is made up of suppliers of plastics, rotomolding company, foundry company, company $\mathrm{C}$ assembling all components, and finally logistics distributors and retailers.

These observations are in line with phenomena described in the literature.

\section{A supply chain is characterized by three flows types}

The supply chains of the three companies are crossed by physical flows.

Company A's supply chain is traversed by watch components, plastics, plastic watches among other. Company B's supply chain is traversed by electronic components, sensors and video among other. Company C's supply chain is traversed by plastics, cast iron molds and polyethylene fences among other.

The supply chains of the three companies are crossed by information flows.

Each company orders resources to its suppliers: components and plastic for company A, sensors for company $\mathrm{B}$ and cast iron molds for company $\mathrm{C}$. Moreover, there are exchanges with their distributors (A and $\mathrm{C}$ ), customers and partners ( $\mathrm{B}$ and $\mathrm{C}$ during the installation of the product).

The supply chains of the three companies studied are crossed by financial flows. All companies pay their suppliers (components and plastic supplier for company A, sensors, electrononic components, video processing for company $\mathrm{B}$, plastics, cast iron molds and rotomolding services for company C). Financial flows include resellers (companies A and $\mathrm{C}$ ), distributors (company B).

These observations are in line with phenomena described in the literature.

A supply chain is composed of processes detailed in activities:

Each process set up within the supply chain is made up of activities facilitating the process. These activities are divided into tasks, carried out by individuals within the companies in the supply chain. The choice of the process is the trigger element in the layout of the future supply chain, as it determines the relevant skills and equipment and informs about the type of the stakeholders.

Within the company A's supply chain, there are:

- Technical processes: assembly, ultrasonic welding ...

- Cross-functional processes: sales, marketing, purchasing

Within the company B's supply chain, there are:

- Technical processes: embedded system, programming, assembly of sensors, interfacing of the embedded system, sensors implementation...

- Cross-functional processes: sales marketing, purchasing ...

Within the company C's supply chain, there are:

- Technical processes: plastic injection, rotomolding, foundry, products installation

- Cross-functional processes: sales, marketing, purchasing, consulting ...

These observations are in line with phenomena described in the literature.

A supply chain generates value.

The company A's supply chain generates financial (increase of turnover), commercial value (increase of its market share), it captures the attention of the customer (increase of customers number) and it generates novelty. The company B's supply chain generates financial (increase of turnover), strategic (differentiation within the market), commercial value (increase of its market share) and offers the associated development opportunity. The company C's supply chain generates financial (increase of turnover), strategic (differentiation within the market), functional value (increase of the number of product function) and generates novelty.

These observations are in line with phenomena described in the literature.

The confrontation of the results from the literature with the observations highlights the important characteristics of a supply chain. This first analysis is the basis of the future model.

\section{Phase 3: Model development}

\section{1) Elements of conceptual modeling data}

As a methodological approach, System Engineering (SE) plays an important role in representing the theory of a system and its complexity, the result of the type and number of elements and the relationships between them[48]. As part of the development of a product and its supply chain, this approach allows the complex system to be decomposed in 
different layers, the identification and organization of activities and the control of the information needed to elaborate the product and the supply chain [48].

To represent a model, the System Engineering use entities linked by relationship. Cardinalities and constrains give information to get as close as possible to reality.

An entity is a set of objects that belongs to its system composed of information characterizing it as an attribute. Within a model, a relationship is a link between entities. There are different types of relationships.

TABLE I. TYPES OF RELATIONSHIP IN THE UML LANGUAGE

\begin{tabular}{|c|c|}
\hline A & $\begin{array}{l}\text { Association: equality relation between two } \\
\text { elements } \\
\text { A uses B }\end{array}$ \\
\hline$(\cdots, \cdots \cdots \cdots, \cdots\rangle$ & $\begin{array}{l}\text { Dependency: two elements but one depends } \\
\text { on the other } \\
\text { A depends on } B\end{array}$ \\
\hline & $\begin{array}{l}\text { Aggregation: an element is an optional } \\
\text { component of the other } \\
\text { A participates in the composition of } B \\
\text { without being essential to its functioning }\end{array}$ \\
\hline & $\begin{array}{l}\text { Composition : one element is a compulsory } \\
\text { component of the other } \\
\text { A participates in the composition of } B \text { and is } \\
\text { essential to it }\end{array}$ \\
\hline & $\begin{array}{l}\text { Generalization: dependency of filiation type } \\
\text { between two elements } \\
A \text { is a kind of } B\end{array}$ \\
\hline
\end{tabular}

The cardinality associated with an association, aggregation or composition termination declares the number of objects that can occupy the position defined by the association termination. Several cardinalities are conceivable:
TABLE II. TYPES OF CARDINALITIES IN THE UML LANGUAGE

\begin{tabular}{|l|l|}
\hline 1 & 1 object exactly \\
\hline$*$ & Several objects \\
\hline $1 \ldots *$ & 1 object at least \\
\hline $1 \ldots \mathrm{N}$ & From 1 to $\mathrm{N}$ objects \\
\hline
\end{tabular}

Within a model, certain entities can be constrained to get as close as possible to reality. Several constrains are conceivable:

TABLE III. TYPES OF CONSTRAINS IN THE UML LANGUAGE

\begin{tabular}{|c|l|}
\hline $\begin{array}{c}\text { Exclusion } \\
\mathrm{E}\end{array}$ & $\begin{array}{l}\text { If an entity participates in the relationship } \\
\mathrm{R} 1, \text { it cannot participate in the relationship } \\
\mathrm{R} 2 .\end{array}$ \\
\hline $\begin{array}{c}\text { Simultaneity } \\
\mathrm{S}\end{array}$ & $\begin{array}{l}\text { Any entity participating in R1 participates } \\
\text { simultaneously in R2. }\end{array}$ \\
\hline $\begin{array}{c}\text { Totality } \\
\mathrm{T}\end{array}$ & $\begin{array}{l}\text { Each entity participates at least in one of the } \\
\text { two relations R1 or R2. }\end{array}$ \\
\hline $\begin{array}{c}\text { Exclusion } \\
\text { and Totality } \\
\text { E and T }\end{array}$ & $\begin{array}{l}\text { Each entity participates at least in either the } \\
\text { relations R1 or the relation R2, but not both } \\
\text { at the same time. }\end{array}$ \\
\hline $\begin{array}{c}\text { Inclusion } \\
\mathrm{I}\end{array}$ & $\begin{array}{l}\text { If an entity participates in the relation R1, it } \\
\text { also participates in the relation R2. }\end{array}$ \\
\hline
\end{tabular}

\section{2) Model description}

The proposed model is decomposed into four interrelated boxes. Note that the environment around the supply chain is not taken into account in the current representation. The boxes are: actors, flows between actors, processes represented through tasks and finally value.

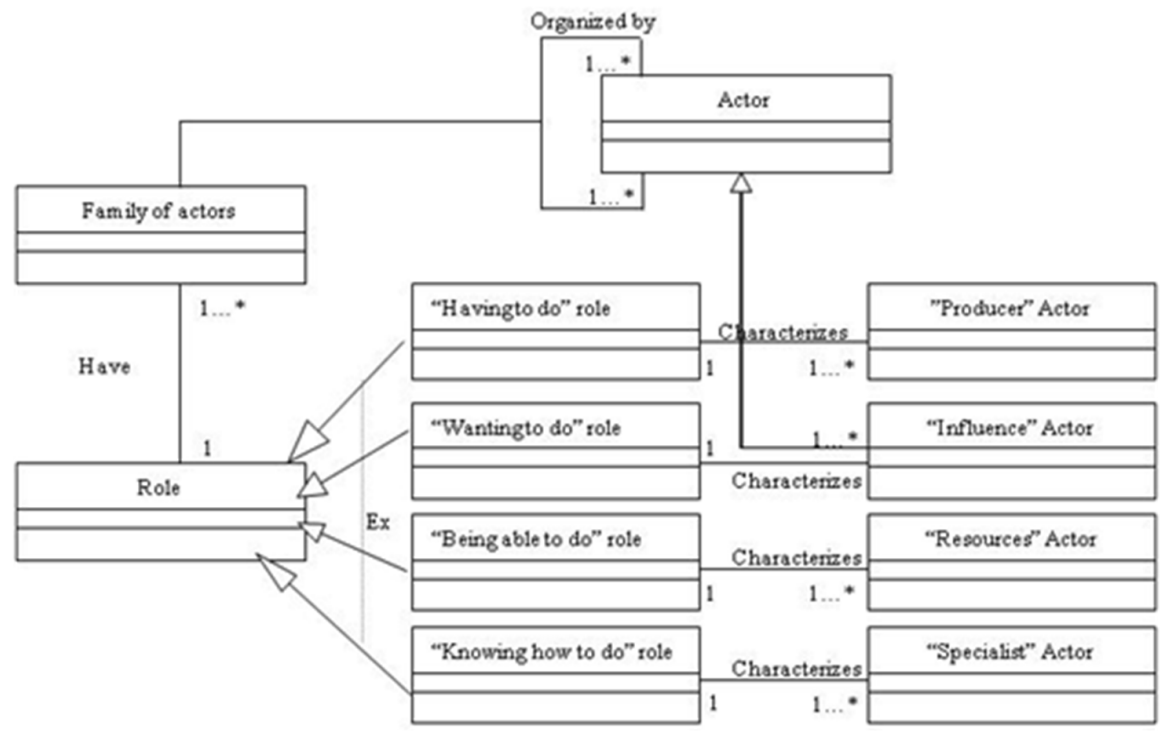

Fig 2. Representation of actors and their role in a UML class diagram 


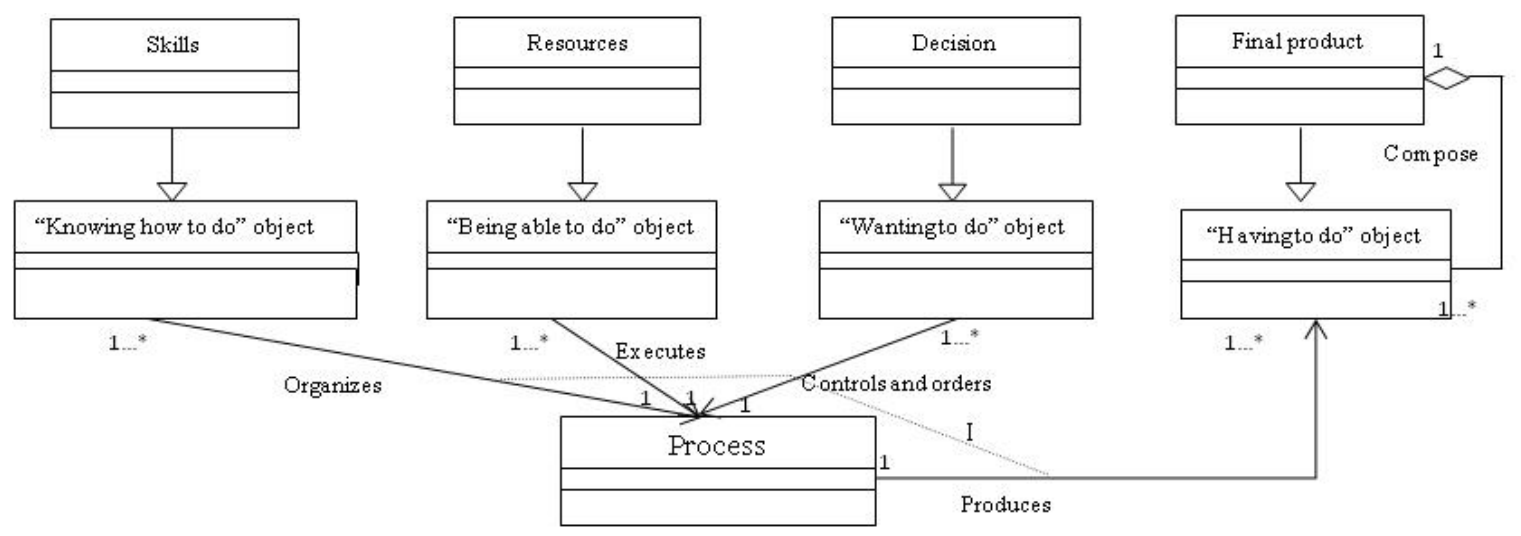

Fig 3. Representation of process in a UML class diagram

Within the model, each actor belongs to a family of actors having the same role (supplier, subcontractor...). Roles may be characterized with attributes like: having to do, knowing how to do, being able to do and wanting to do (Figure 2).

To produce a "Having to do" object, here a component or a final product, the process uses skills ("Knowing how to do" object), resources ("Being able to do" object) and decisions ("Wanting to do" object) [49]. All these elements are necessary to realize the product (Figure 3). At least, one skill, one resources and one decision is needed to operate a process and make at least one tangible or intangible product. Each actor is connected to the other ones through flows (Figure 4).
A process can be decomposed into at least one activity. Each of these activities creates at least one type of value. The figure 5 represents part of the model, dedicated to process decomposition and value generation. This part is directly linked to the resources needed to manufacture the product and the actors.

The global model is presented in figure 6 .

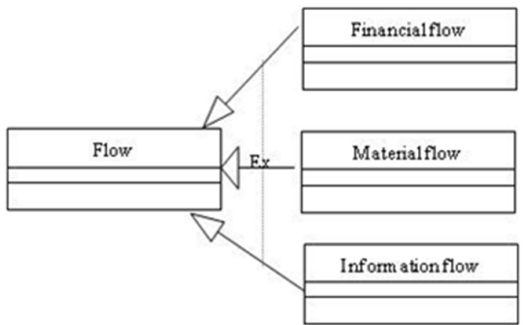

Fig 4. Representation of flows and their type in a UML class diagram

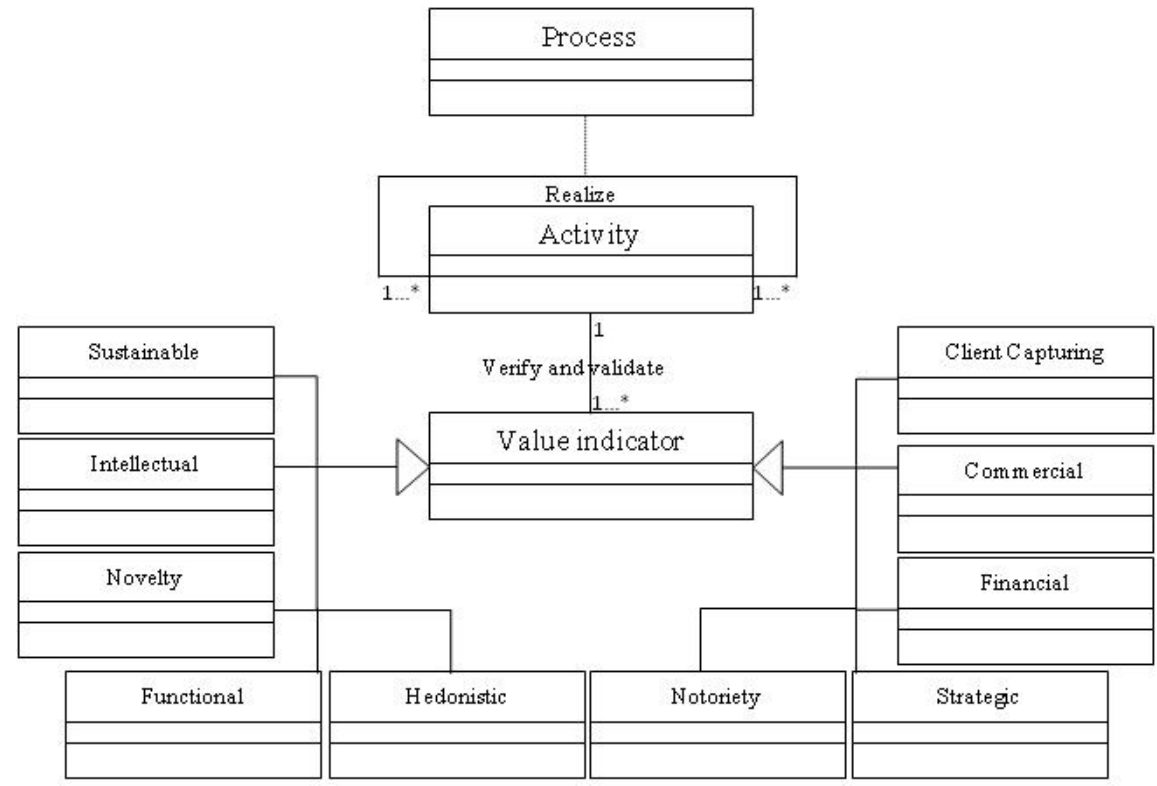

Fig 5. Representation of activities in a UML class diagram [45] 


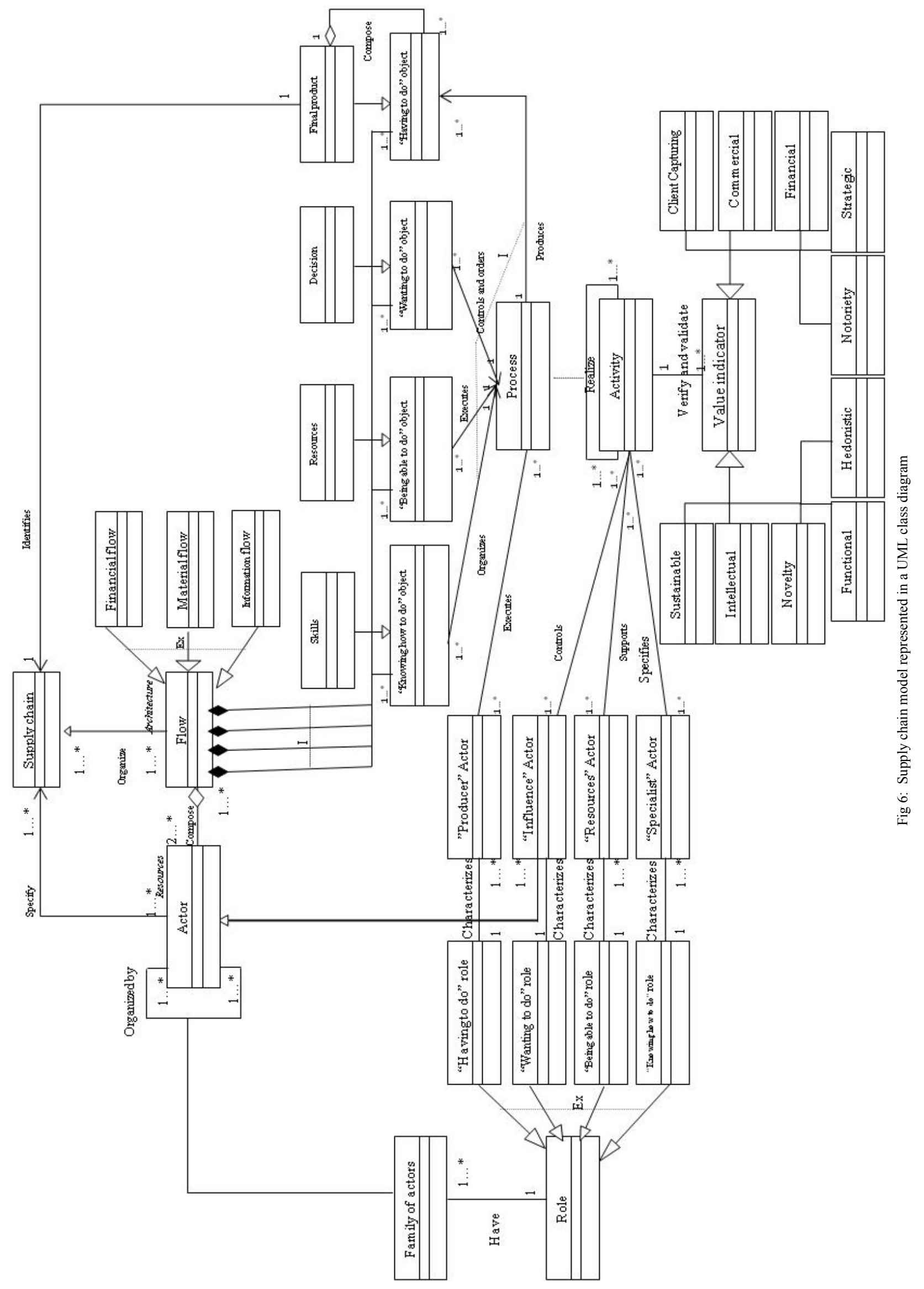


The proposed model represents a step in the supply chain process at a specific time.

\section{Phase 4: Validation}

\section{1) Instantiation of the model}

Company $\mathrm{D}$ is a company specializing in ball bearing for industry, automotive and aeronautical sectors. Essentially aimed at the automotive industry, the new product in development is an electromagnetic sensor integrated into bearings to offer an alternative to current ABS technology. This product consists of a magnet and a sensor, sensitive to the external magnetic field to vary the electrical resistance of the assembly The model was completed as follows:

- The product has been decomposed into modules and components;

- Each module or component has been decomposed into a process;

- Tasks have been assigned to each process;

- Skills, resources and decisions were assigned to each task;

- Actors have been defined according to the skills and resources used to carry out the tasks;

- The generated value has been determined.

The decomposition into modules and components enable prioritizing the manufacturing of the product and highlights the manufacturing steps. The manufacturing processes for each item were added based on information from the design phase. Each process was decomposed into tasks by interviewing the product design team.

In the case of the magnetic sensor, the $\mathrm{TAB}$ assembly process is:

\begin{tabular}{|c|c|c|}
\hline Activity & Skills & Resources \\
\hline $\begin{array}{l}\text { - Supply of materials } \\
\text { - Position the electrical } \\
\text { components, electronic } \\
\text { components in the order of } \\
\text { assembly } \\
\text { - Assemble the elements } \\
\text { - Check product compliance }\end{array}$ & $\begin{array}{l}\text { Electricity, Electronic } \\
\text { Electromechanical } \\
\text { Gluing technique } \\
\text { Reading technical } \\
\text { documents } \\
\text { Tools using } \\
\text { Welding, Brazing }\end{array}$ & $\begin{array}{c}\text { Reader head } \\
\text { Differential } \\
\text { Amplifier } \\
\text { Copper } \\
\text { threads } \\
\text { Flex circuit }\end{array}$ \\
\hline
\end{tabular}

Skills and resources were assigned to each task and allowed to define the role of the actors in charge of these processes. In this example, this information allows determining the characteristics of the actors. Therefore, this component of the final product can be developed by company operating in the field of electronics. The decomposition into tasks and skills enable formulating useful requirements when choosing the company in charge of the manufacture of this component in the supply chain.
The expertise of the interviewees validates the existence of influence actors including normative and governmental instance or the customer (here an automotive designer) and the need for specialist actors playing the role of subcontractors. They are stakeholders who integrate the supply chain with the help of a decision-maker. The manufacture of the sensor does not require the intervention of Influence Actor or Specialist Actor. However, the Resource Actor is required. It refers to the companies that provide the resources needed to manufacture the component or product. In this case, the Resource Actor corresponds to the reader head and differential amplifier suppliers. The figure 8 shows the application of the model to the example "TAB assembly process".

This third phase highlighted that some "boxes" of the model cannot be fulfilled, for lack of information on the subject. This situation appears in the definition of the actors in charge of the manufacture of the sensor bodies. The complexity degree of shape influences the manufacturing process: a complex shape would involve 3D printing, while a simple shape would require conventional machining. This observation is important, emphasizing this fuzzy zone within the supply chain, it is a warning for the innovative company that a brake may be presented and that it has to act to ensure the success of its product.

\section{2) Conclusion concerning the model validation}

Thanks to the results from the literature and the exploratory cases, a supply chain model was developed. This model was refined through an application, review and modification process. The result is a model capturing the skills and activities associated with a process specific to a stakeholder in the supply chain. This model is a first step in the structuring of the future supply chain.

In the case of company $\mathrm{D}$, the results provided by the model were presented to the top management whose expertise highlighted some details to be considered, in particular the degree of precision to be displayed concerning the processes or the skills. The wide range of processes and skills complicates the prediction of the future supply chain.

Several solutions are envisaged to overcome this problem in order to elaborate a prospective analysis tool: to build a database generated from the information provided by voluntary companies or to design a database based of the information provided by French public institutions in charge of employment. The first solution provides accurate information on very specific processes and skills but requires co-design of the database, while the second solution offers a wide range of skills and processes to a much lower degree of accuracy. The ideal would be to merge these two solutions in order to perpetuate the tool over the long term. 


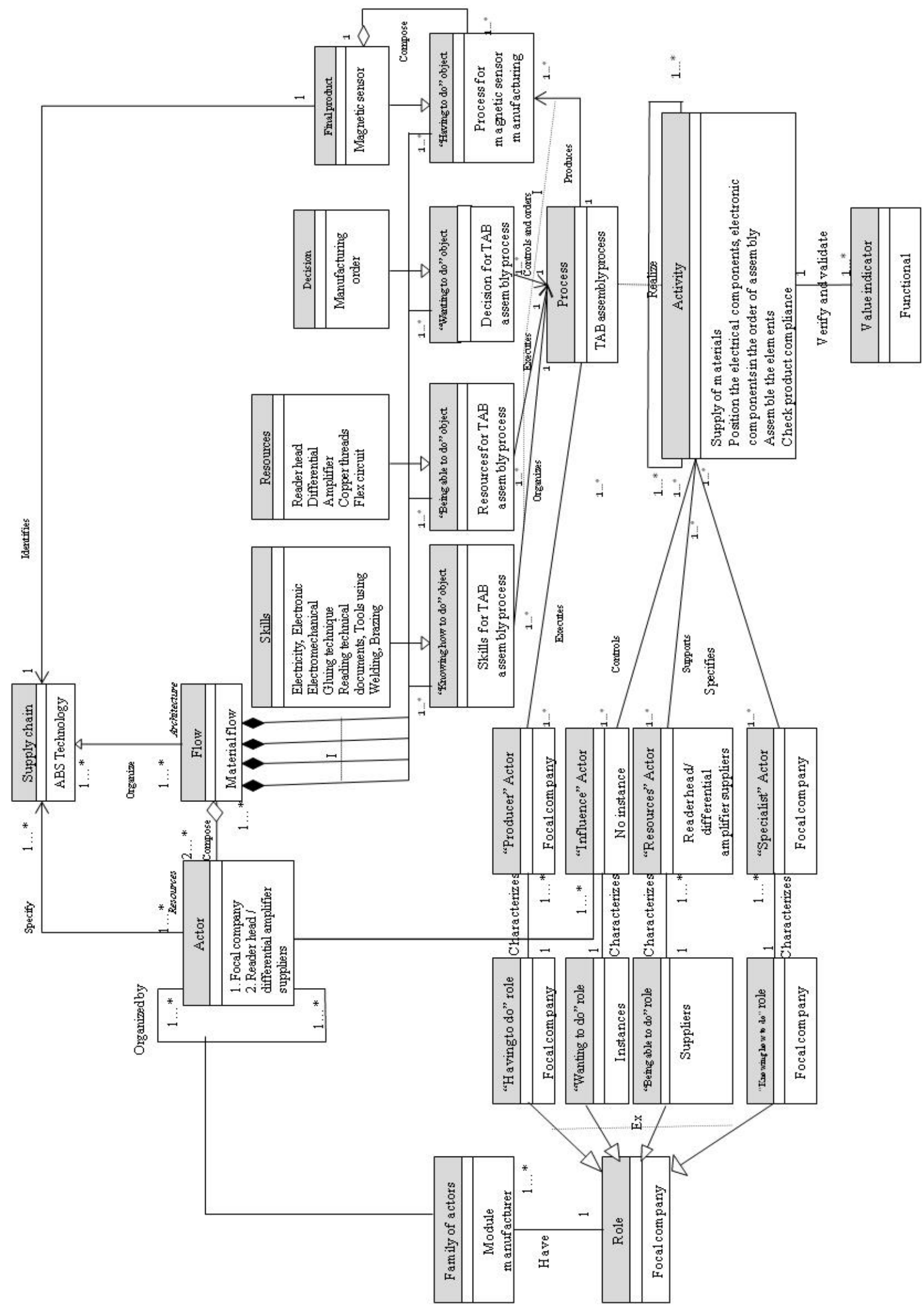

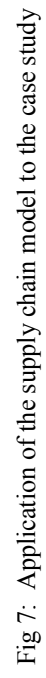




\section{CONCLUSION}

This research validates the characteristics of a supply chain from the literature thanks to exploratory cases in order to better understand this ecosystem. The research outcome is represented by a system modeled according to a System Engineering Based on the Models in order to underline the interdependencies between the constituent elements of a supply chain. The main contributions of this work are:

- A systemic model based on evidence and literature;

- A reality-based representation that synthesizes the constitutive elements of any supply chain from a wide variety of source that integrate the literature of multiple domains;

- A valid basis for the design of a future supply chain prospective analysis tool;

- An overview of the importance of the supply chain in the design of an innovative product.

This research focuses on the correlation between the product and its supply chain, hence the need to link the product system to the supply chain system. The product architecture has to be aligned with the supply chain. Knowing the architecture of the system brings several advantages [50]. By organizing and structuring the system, the architecture provides a global perspective of information resources, eliminating redundancy in processes. A decomposition of the product appears to be a good alternative to identify information specific to the design and manufacture of the product. Apart from the perfect type of supply chain for a new product other considerations might also determine the optimal supply chain:

- The availability of an existing supply chain with partners for the other products produced by the company.

- The supply chain of competitors and the possibility to protect the new supply chain against competitors.

The choice of the modeling based on the System Engineering allows a capitalization of the information in the databases. In perspective a complementary prospective analysis tool for supply chain design is required, as it will highlight the design invariants as well as the motor and dependent variables and will thus consolidate the knowledge bases for future research.

\section{REFERENCES}

[1] M. L. Christopher, Logistics and Supply Chain Management, Pitman Publishing. Londres, 1992.

[2] G. C. O'Connor et M. P. Rice, «New Market Creation for Breakthrough Innovations: Enabling and Constraining Mechanisms ", 2013

[3] M. L. Fisher, "What Is the Right Supply Chain for Your Product? ", Harv. Bus. Rev., vol. 75, nº 2, p. 105-116, avr. 1997.

[4] M. A. Vonderembse, M. Uppal, S. H. Huang, et J. P. Dismukes, " Designing supply chains: Towards theory development ", Int. J. Prod. Econ., vol. 100, nº 2, p. 223-238, avril 2006.

[5] J. De Rosnay, Le macroscope. Vers une vision globale, Edition du Seuil. 1975
[6] E. Morin, La méthode: Tome 1, La nature de la nature. Paris: Points, 1977.

[7] S. D. Eppinger et T. R. Browning, Design Structure Matrix Methods and Applications. MIT Press, 2012

[8] M. Weigt, " Implications of Complexity in Early Stages of Innovation Processes for the Definition of Heuristic Engineering Methods ", in The Future of Product Development, P. D.-I. F.-L. Krause, Éd Springer Berlin Heidelberg, 2007, p. 135-144.

[9] G. Simondon, Du mode d'existence des objets techniques. Paris: Editions Aubier, 1958

[10] K. Ulrich, " The role of product architecture in the manufacturing firm ", Res. Policy, vol. 24, n 3, p. 419-440, 1995.

[11] H. A. Simon, «The Architecture of Complexity », Proc. Am. Philos. Soc., vol. 106, no 6, p. 467-482, 1962.

[12] E. Castro, F. Mayer, et P. Lhoste, «Contribution to the Formalization of Individualized Processes during Product Innovation », présenté à 3rd European Conference on Management of Technology, EUROMOT, Nice, France, 2008, vol. 8, p. 200

[13] G. Assogba et S. Klebaner, «Vers un cadre d'analyse institutionnaliste de la politique de filière: Quelle cohérence pour la politique de filière française? ", Cahiers du GREThA, n²015 - 26, 2015 .

[14] H. Stadtler et C. Kilger, Supply Chain Management and Advanced Planning: concepts, models, software and case studies, Editions Springer Verlag. 2002.

[15] R. Feenstra, "Integration of Trade and Disintegration of Production in the Global Economy", Journal of Economic Perspectives, p. 31-50, 1998

[16] OCDE, « Moving up the Global Value Chain », L'observateur OCDE, 2007.

[17] L. T. M. Blessing, A. Chakrabarti, et K. M. M. Wallace, «A design research methodology», in Proceedings of the 10th International Conference on Engineering Design (ICED'95), Prague, Czech Republic, 1995, vol. 23, p. 50-55.

[18] C. M. Eckert, M. K. Stacey, et P. J. Clarkson, « The spiral of applied research: A methodological view on integrated design research», présenté à Proceedings of the 14th International Conference on Engineering Design (ICED'03), Stockholm, Sweden, 2003.

[19] C. Swann, " Action Research and the Practice of Design", Des. Issues, vol. $18, \mathrm{n}^{\circ} 1$, p. 49-61, janv. 2002.

[20] F. Bulinge, Maîtriser l'information stratégique: Méthodes et techniques d'analyse, 1re éd. Bruxelles; Paris: De Boeck, 2014.

[21] G. I. Susman et R. D. Evered, «An Assessment of the Scientific Merits of Action Research », Adm. Sci. Q., vol. 23, n 4, p. 582-603, 1978

[22] J. Moultrie, P. J. Clarkson, et D. Probert, " Development of a Design Audit Tool for SMEs ", J. Prod. Innov. Manag., vol. 24, $\mathrm{n}^{\mathrm{o}} 4$, p. 335-368, juill. 2007.

[23] C. Chatelin, " Epistémologie et méthodologie en Sciences de gestion: réflexion sur l'étude de cas ". Document de recherche, 2005.

[24] P. Gomez, «Modelle und Methoden des systemorientierten Managements ». Bern: Haupt., 1981.

[25] D. Durand, La systémique, 12e édition revue et corrigée. PRESSES UNIVERSITAIRES DE FRANCE - PUF, 1979.

[26] S. Rochet, "Formalization of System Engineering Processes : Proposal of a method to adapt generic processes to different application contexts", Theses, Université Paul Sabatier - Toulouse III, 2007.

[27] M. Fleischmann, J. M. Bloemhof-Ruwaard, R. Dekker, E. van der Laan, J. A. E. E. van Nunen, et L. N. Van Wassenhove, " Quantitative models for reverse logistics: A review ", Eur. J. Oper. Res., vol. 103, no 1 , p. 1-17, nov. 1997.

[28] T. Gaucheron, Intégration du recyclage en conception le modèle produit: un outil descriptif et cognitif dans le processus de prise en compte du recyclage. INP GRENOBLE, 2000.

[29] Y. Pimor, Logistique: techniques et mise en oeuvre, Dunod. 2001.

[30] C. Maudet-Charbuillet, "Proposition d'outils et démarches pour l'intégration de filières de recyclage de matières plastiques dans la "supply chain" automobile.", phdthesis, Arts et Métiers ParisTech, 2009 . 
[31] M. Christopher, Logistics and Supply Chain Management, Financial Times. London, 1998.

[32] G. Paché, "Le pilotage des chaînes logistiques multi-acteurs: une lecture critique des pratiques collaboratives ", Econ. Sociétés, vol. 38, $\mathrm{n}^{\circ} 12$, p. 2133-2154, 2004.

[33] V. Carbone, "Le rôle des prestataires logistiques en Europe Intégration des chaînes et alliances logistiques ", phdthesis, Ecole des Ponts ParisTech, 2004.

[34] L. R. Kopczak, "Logistics Partnerships and Supply Chain Restructuring: Survey Results from the U.s. Computer Industry", Prod. Oper. Manag., vol. 6, nº 3, p. 226-247, sept. 1997.

[35] L. Lapide, "What about measuring supply chain performance", Achiev. Supply Chain Excell. Technol., vol. 2, no 2, p. 287-297, 2000.

[36] N. Tchernev, " Modélisation du processus logistique dans les systèmes flexibles de production ", Doctoral dissertation, 1997.

[37] P. Féniès, "Une méthodologie de modélisation par processus multiples et incrémentiels: application pour l'évaluation des performances de la Supply Chain ", phdthesis, Université Blaise Pascal - Clermont-Ferrand II, 2006.

[38] S. E. Fawcett et G. M. Magnan, Achieving world-class supply chain alignment: benefits, barriers, and bridges. 2001.

[39] K. Lysons et M. Gillingham, Purchasing and Supply Chain Management, 6e edition. Prentice Hall, 2003.

[40] P. Lorino et J.-C. Tarondeau, " De la stratégie aux processus stratégiques ", Rev. Fr. Gest., vol. no 160, nº 1, p. 307-328, 2006.

[41] C. Romeyer, Système d'information fondé sur une traçabilité des activités : intérêt et difficultés de mise en oeuvre dans les hôpitaux. Aix Marseille 2, 2001.

[42] P. Lorino, Méthodes et pratiques de la performance: le pilotage par les processus et les compétences, Ed. d'organisation. 2003.

[43] J.-P. Meinadier, Ingénierie et intégration des systèmes. Paris: Hermes Science Publications, 2002.

[44] E. Castro Espiritu, "Contribution à l'ingénierie de l'innovation: Proposition d'un cadre de modélisation pour un système d'innovation centré sur le produit", Doctoral dissertation, INPL, Vandoeuvre-lesNancy, 2010.

[45] V. Boly, M. Camargo, et L. Morel, Ingénierie de l'innovation, 3è édition. Hermes Science Publications, 2016.

[46] C. Aguillaume, " Les horlogers suisses face à la mondialisation (19681983) ", Cah. Récits, nº 3, p. 57-76, 2004.

[47] G. Garel et E. Mock, La fabrique de l'innovation, Dunod. Paris, 2012.

[48] E. Bonjour et M. Dulmet,"Pilotage des activités de conception par l'Ingénierie Système (IS). ", in Ingénierie de la conception et cycle de vie des produits, H. Science, Éd. Lavoisier, 2006, p. 85-105.

[49] F. Mayer, "Social impact of automation trends and issues: an human centred systems engineering perspective. ", IFAC Proc. Vol., vol. 41, $\mathrm{n}^{\circ} 2$, p. 5251-5256, 2008.

[50] C. Marques Pereira et P. Sousa, " A Method to Define an Enterprise Architecture Using the Zachman Framework ", in Proceedings of the 2004 ACM Symposium on Applied Computing, New York, NY, USA, 2004, p. 1366-1371. 